\title{
How do urban characteristics affect climate change mitigation policies?
}

\author{
Hidemichi Fujii ${ }^{1}$, Kazuyuki Iwata ${ }^{2}$, Shunsuke Managi ${ }^{3 *}$ \\ ${ }^{1}$ Graduate School of Fisheries and Environmental Sciences, Nagasaki University, 1-14 Bunkyo-machi, \\ Nagasaki 852-8521, Japan. \\ ${ }^{2}$ Faculty of Economics, Matsuyama University. \\ ${ }^{3}$ Urban Institute \& Department of Urban and Environmental Engineering, School of Engineering, Kyushu \\ University.
}

*Corresponding author: managi.s@gmail.com

\begin{abstract}
Urban policy plays an important role in urbanization and urban sprawl, which in turn affect changes in $\mathrm{CO}_{2}$ emissions from urban areas. However, urban planning policies that consider climate change mitigation have not been widely adopted, despite the issue's importance. To promote the consideration of climate change policies in urban planning, it is useful to identify the key determinants of effective climate change mitigation for policy makers. The objective of this study is therefore to identify the determining factors that affect changes in urban $\mathrm{CO}_{2}$ emissions based on city type using a dataset of metropolitan areas. We obtained data on 276 cities in 26 countries for the years 2000, 2005, and 2008. We divided the data into five regional groups and four clusters to control for the characteristics of metropolitan areas. The dataset includes urban $\mathrm{CO}_{2}$ emissions, GDP, and population. Three variables related to urban characteristics are subjected to determinants analysis using an econometric approach. The results show that the determinants of changes in urban $\mathrm{CO}_{2}$ emissions differ by city type and region. These results contribute to a better understanding of urban policies that can improve the effects of these driving factors by considering the characteristics of each city type.
\end{abstract}

Keywords: urban policy, $\mathrm{CO}_{2}$ emissions, metropolitan area, urban characteristics, compact city, OECD 


\section{Introduction}

Urban policy plays an important role in urbanization and urban sprawl, which in turn affect changes in greenhouse gas (GHG) emissions from urban areas (Hendrickson et al. 2016). According to Fragkias (2013), 60\%-80\% of global energy use was consumed in urban areas in recent years, and more than $70 \%$ of global GHG emissions are produced within urban areas. The OECD (2014) noted that cities can play a key role in addressing global climate change through smart urban design and planning.

Given this situation, urban climate mitigation activities have been promoted by city leaders to protect their cities against the threat of natural disasters (Rosenzweig et al., 2010). The World Mayoors Council on Climate Change (WMCCC) was founded in 2005 to strengthen cities' commitment to climate change mitigation. In January 2017, 88 members of the council developed a network of local government activities that can reduce GHG emissions. In addition, non-party stakeholders ${ }^{1}$ including city and local governments are required to scale up their climate mitigation activities with the adoption of the Paris agreement (UNFCCC, 2015).

However, urban policies that consider climate change mitigation have not been widely adopted (Broto and Bulkeley, 2013; OECD, 2014), and the trade-off relationship between climate mitigation and economic competitiveness or social issues is one major reason (Viguié and Hallegatte, 2012). Therefore, the balance between economics, social issues, and the environment is an important factor in developing urban sustainability policies because the economic and social situation critically affects the employment ratio and governmental budget resources, which are key components in urban development.

With the increased attention on urban climate policies, the number of studies that focus on urban planning for climate change mitigation and adoption has grown in recent years (Davoudi et al. 2010; Broto, 2017). McDonald et al. (2011) focus on the effects of climate change on future fresh water availability and urban water resources in developing countries. Wamsler et al. (2013) propose a conceptual framework for a city disaster nexus that includes urban risk reduction and adaptation strategies for climate change.

Some studies focus on a case study of a specific area. Hendrickson et al. (2016) apply life cycle

\footnotetext{
${ }^{1}$ Accroding to the UNFCCC (2015), non-party stakeholders include civil society, the private sector, financial institutions, cities and other sub-national authorities, local communities and indigenous peoples.
} 
assessment to evaluate San Francisco’s climate change mitigation strategy. Lee and Painter (2015) compare the urban climate change mitigation policies in four cities—Seoul, Busan, Seattle and Anaheim. Damsø et al. (2016) examine the climate action plans of local governments by focusing on the mitigation target level and scope of GHG accounts in Denmark.

There are many studies that analyse urban climate policies and mitigation activities, but few have investigated the key determinants of effective urban climate change mitigation using a large amount of data on metropolitan areas. Additionally, previous studies use cross-country or multiple-city data to identify the key determinants and do not clearly consider the differences in the characteristics of cities and the sources of $\mathrm{CO}_{2}$ emissions, which can significantly affect the determinants of changes in urban $\mathrm{CO}_{2}$ emissions.

Lee and Painter (2015) and Mi et al. (2017) note that cities vary in their procedures for planning and implementing GHG mitigation policies. Dabo et al. (2016) clarify the diversity of the residential carbon footprint among income groups, which strongly affects consumer choice. Additionally, the characteristics of cities are diverse because many conditions differ, including geographies, core industrial sectors, and climate conditions (Fujii and Managi, 2016a; Meng et al., 2017). Therefore, cities implement different urban policies because they have different characteristics, and these characteristics must be considered when analysing appropriate urban planning policies and solutions for climate change mitigation.

Major GHG emissions sources differ among cities due to the cities' characteristics and available energy sources (UNEP, 2012). Figure 1 shows a scatterplot of the share of $\mathrm{CO}_{2}$ emissions in the energy and transport sector for 276 metropolitan areas in $2008^{2}$. As shown in Figure 1, the main sources of $\mathrm{CO}_{2}$ emissions differ among cities. UNEP (2012) notes that climate change mitigation efforts should be consistent with the desired solutions for major $\mathrm{CO}_{2}$ emitting sectors in cities. Thus, effective climate change mitigation policies differ among cities that have different sources of $\mathrm{CO}_{2}$ emissions.

$<$ Figure 1 about here $>$

\footnotetext{
${ }^{2}$ The energy sector includes public electricity, heat production, and other energy industries. The transport sector includes road, rail, and ground transportation.
} 


\section{Literature Review}

There are multiple potential $\mathrm{CO}_{2}$ emissions sources in cities, such as the transport, industrial, household, commerce and energy sectors, because a city's economic activities are diverse. Additionally, the characteristics of cities are diverse because many conditions differ, including geographies, core industrial sectors, and climate conditions (Fujii and Managi, 2016a; Meng et al., 2017). Therefore, a number of studies from various academic fields have examined the relationship between city characteristics and the $\mathrm{CO}_{2}$ emissions from corresponding sectors.

When urban forms are changed, including new construction of infrastructure, the most influenced emissions source is the transportation sector because the flows of people and the logistics are changed. Noman et al. (2006) conclude that the most important target for reducing $\mathrm{CO}_{2}$ emissions is the transport sector. One of the most well-known studies from the first era of such studies is Newman and Kenworthy (1989). Using data from large cities around the world from 1980, they show that per capita gasoline consumption (i.e., $\mathrm{CO}_{2}$ emissions from vehicles) is higher in low density cities than in high density cities. However, the authors do not consider the other social and economic factors that can influence consumption. Glaeser and Kahn (2010) account for social and economic factors in their analysis and find that $\mathrm{CO}_{2}$ emissions from vehicles are negatively correlated with population density based on data from 66 large cities in the United States. Using Japanese city data from 1990 to 2010, Iwata and Managi (2016) show the same relationship and conclude that urban policies such as property taxes and land use regulations can be used to increase population densities, thereby reducing $\mathrm{CO}_{2}$ emissions from vehicles.

With regard to the household sector, Makido et al. (2012) define an index of city complexity and compare 15 Japanese cities using data from 2005. They find that residential per capita $\mathrm{CO}_{2}$ emissions are lower in less complex cities than in highly complex cities. Analysing 30 provincial capital cities in China, Fang et al. (2015) support the reduction of complexity as a measure for climate change mitigation. Ahmad et al. (2015) analyse approximately 19,000 households' $\mathrm{CO}_{2}$ emissions data in India, including electricity and cooking, and show that households in high density cities are likely to have lower $\mathrm{CO}_{2}$ emissions than in low density cities. Noman et al. (2006) divide the Toronto metropolitan area into low and high density areas and compare three types of per capita $\mathrm{CO}_{2}$ emissions (i.e., transportation, building operations and building materials). The authors conclude that all three types of per capita $\mathrm{CO}_{2}$ emissions are lower in high 
density areas than in low density areas. Therefore, urbanization helps to reduce residential $\mathrm{CO}_{2}$ emissions, not only in developed countries but also in developing counties.

Instead of analysing different sectors' $\mathrm{CO}_{2}$ emissions, several studies employ a top-down approach, that is, they examine the relationship between the urban form and total $\mathrm{CO}_{2}$ emissions. Marcotullio et al. (2012) extract data for 3,535 urban areas from 45 Asian countries and find that total $\mathrm{CO}_{2}$ emissions in urban areas are negatively associated with population density. Using a large dataset from 40 countries in Europe that covers 1,153 cities with more than 50,000 residents, the same research team, Marcotullio et al. (2014), modify the STIRPAT model to examine the determinants of total $\mathrm{CO}_{2}$ emissions. The results show that population density is strongly and negatively associated with emissions. Alli et al. (2017) examine the relationship between urbanization (i.e., urban population) and total $\mathrm{CO}_{2}$ emissions using a long-term dataset from 1970 to 2015 in Singapore, a unique island-city-country. Their main finding is that urbanization is negatively and significantly correlated with emissions. These studies also imply that the promotion of urbanization and increases in population density can mitigate climate change by reducing $\mathrm{CO}_{2}$ emissions from the household sector.

The literature advocates urban policies such as those described above for combatting climate change. However, some studies reveal different relationships. Zhang and Lin (2012) divide China into eastern, central and western regions and separately analyse the relationship between urbanization (i.e., the share of the urban population) and total $\mathrm{CO}_{2}$ emissions. Using provincial panel data from 1995 to 2010, they find heterogeneous effects of urbanization on total $\mathrm{CO}_{2}$ emissions. In particular, a positive relationship is found in the central region, suggesting that urbanization worsens climate change, and therefore the appropriate urban policies are not the same among regions. This finding is in line with the conclusion of Meng and Huang (2017). In addition, Liddle (2014) mainly reviews prior studies using macro/country-level data and finds that recent studies reach diverse conclusions.

The diverse conclusions in the literature must be a result of the complexity of cities' forms and functions as well as the diversity of geographic, climatic, social, and cultural characteristics among cities and countries, which implies that we should tailor urban policies based on the situation in each city and country. When analysing the relationship between the city form and $\mathrm{CO}_{2}$ emissions, most recent studies control for not only socio-economic factors but also geographic and climate conditions. However, few 
studies consider the structure of emissions sources. For example, most studies do not explicitly distinguish among cities with high shares of $\mathrm{CO}_{2}$ emissions in the energy industry and in the transportation industry. Therefore, in parallel with controlling for socio-economic, geographic and climate factors, we overcome this gap in the literature by employing a cluster analysis, which will be explained in section 3.1. Then, we employ determinants analysis in order to identify tailored urban policies.

Given this background, the objective of this study is to identify the determining factors that affect urban $\mathrm{CO}_{2}$ emissions and intensity based on city type using a dataset of metropolitan areas from the OECD.stat database. We obtain data for 276 cities in 26 countries for the years 2000, 2005, and 2008. The dataset includes urban $\mathrm{CO}_{2}$ emissions, GDP, and population. These three variables are applied to the decomposition analysis. Additionally, data on compact city and urban policy variables are applied to the determinants analysis using an econometric approach (see Figure 2). Because the characteristics of cities are diverse, we divide the sample by city type and focus on the share of $\mathrm{CO}_{2}$ emissions from the energy industry, transport, and other sources using cluster analysis, which reflects a determinants approach to identifying the driving factors of changes in urban $\mathrm{CO}_{2}$ emissions and intensity based on city characteristics.

$<$ Figure 2 about here $>$

\section{Data and Methodology}

3-1. Data sample and grouping

We obtained urban $\mathrm{CO}_{2}$ emissions and social data from the database of metropolitan areas in OECD.stat (OECD, 2012). This database covers 281 metropolitan areas with a population of 500,000 or more in 30 OECD countries for the years 2000, 2005, and 2008. ${ }^{3}$ Because GDP data for five metropolitan areas (Oslo,

\footnotetext{
${ }^{3}$ According to the OECD (2012), the estimation of $\mathrm{CO}_{2}$ emissions data uses the EDGAR global emissions database (version 4.1), which was developed by the Joint Research Centre of the European Commission. The methodology employed essentially sums the EDGAR estimated values for 0.1-by-0.1 degree grids over the relevant boundaries of the metropolitan areas.
} 
Zurich, Geneva, Basel, and Copenhagen) are unavailable from OECD.stat, we excluded them from the dataset. Thus, we used data on 276 metropolitan areas, which are listed in Appendix 1.

We divided the data on the 276 cities into five regional groups (see Appendix 1) and four clusters in order to understand the effects of a metropolitan area's characteristics. In the regional grouping, the first group is the U.S. region, where people mainly use automobiles over long distances. The second group is the EU, which has produced an advanced urban planning policy for environmental protection. The third group is Japan and Korea (JP\&KR), which has high population density. The fourth group is Australia and Canada (AU\&CA), which have large land areas and low population density. The fifth group is Chile and Mexico (CL\&MX), which are developing countries.

As shown in Figure 2, this study applies a three-step approach to investigate the determinants of changes in urban $\mathrm{CO}_{2}$ emissions by city type. First, we apply a k-means partition cluster analysis for the share of $\mathrm{CO}_{2}$ emissions in each sector to identify the urban $\mathrm{CO}_{2}$ emissions characteristics. The advantage of a k-means partition cluster analysis is that it can treat a large dataset using a concise algorithm better than other types of cluster analysis (Li et al., 2016). K-means partition cluster analysis is widely applied in research fields related to urban economics and urban planning (Chévez et al., 2017). Figure 3 shows the results of the cluster analysis using the share of $\mathrm{CO}_{2}$ emissions from the energy industry, transport, and other sectors.

$<$ Figure 3 about here $>$

In Figure 3, we can see the characteristics of each cluster group. Cluster 1 tends to have a high share of $\mathrm{CO}_{2}$ emissions in the energy industry and a low share in the transport sector. Meanwhile, the cities in cluster 3 have high shares of $\mathrm{CO}_{2}$ emissions in the transport sector and low shares in the energy industry. Thus, these two clusters have the opposite characteristics with regard to the main $\mathrm{CO}_{2}$ emissions source. Additionally, the cities in cluster 2 tend to be close to the origin, which means that the share of $\mathrm{CO}_{2}$ emissions in the other sector is high. Cluster 4 maintains a balance in the share of $\mathrm{CO}_{2}$ emissions from the three sectors. Based on these results, we call cluster 1 (C1) the energy-industry-oriented group, cluster 2 
(C2) the other-sector-oriented group, cluster 3 (C3) the transport-sector-oriented group, and cluster 4 (C4) the balanced group.

\section{3-2. Variables}

Table 1 shows the variables and their descriptions. $\mathrm{CO}_{2}$ emissions data are available for three types of variables: [1] $\mathrm{CO}_{2}$ emissions per capita, [2] $\mathrm{CO}_{2}$ emissions per capita from the energy industry, and [3] $\mathrm{CO}_{2}$ emissions per capita from transport. We create the category " $\mathrm{CO}_{2}$ emissions per capita from other sectors” using the above three variables (see definition in Table 1). Additionally, we generate variables for the share of $\mathrm{CO}_{2}$ emissions from each sector for the cluster analysis.

$<$ Table 1 about here $>$

We can decompose the $\mathrm{CO}_{2}$ emissions intensity (INTENSITY), defined as $\mathrm{CO}_{2}$ emissions per unit of GDP, using the following equation:

$$
\text { INTENSITY }=\mathrm{CO}_{2} / \mathrm{GDP}=\mathrm{CO}_{2} \text { per } / \text { GDPper. }
$$

In this case, INTENSITY is defined by the ratio between $\mathrm{CO}_{2}$ emissions per capita and GDP per capita. If the scale of economic activity declines, $\mathrm{CO}_{2}$ emissions will decrease due to the scaling down of production, and consumption behaviour and GDP will decrease (Fujii and Managi, 2016b). As a result, INTENSITY is not greatly affected by a change in the economic situation. Thus, INTENSITY controls for the effect of changes in the economic situation caused by business cycles.

Many studies focus on the relationship between economic development (i.e., GDP per capita) and $\mathrm{CO}_{2}$ emissions per capita, although a clear relationship has not been observed ${ }^{4}$. Thus, GDP per capita and $\mathrm{CO}_{2}$ emissions per capita do not have a clear trade-off or proportional relationship. Based on this

\footnotetext{
${ }^{4}$ For example, environmental Kuznets curves for city data (Wang and Ye, 2016), OECD countries (Fujii and Managi, 2013), and global data (Dong et al., 2016) .
} 
background, we assume that GDP per capita and $\mathrm{CO}_{2}$ per capita can be independently changed. In this case, the identification of the determinants of each driving factor is important in order to construct an effective and appropriate urban policy for GDP per capita growth and $\mathrm{CO}_{2}$ per capita reduction.

Another benefit of applying a decomposition framework is to distinguish among the effects of the determinant variables. Based on equation (1), there are several ways to decrease INTENSITY. One way is to decrease $\mathrm{CO}_{2}$ emissions per capita while maintaining GDP per capita, while another way is to increase GDP per capita while maintaining $\mathrm{CO}_{2}$ emissions per capita. To investigate the relationship between the decomposed variables and the determinants, we can examine the influence path of each determinant of INTENSITY by considering the coefficients of the determinants for each decomposed factor (see Figure 2).

As explained in Table 1, DENS, COMM, and CORE are applied as determinant variables of urban $\mathrm{CO}_{2}$ intensity. Previous studies have attempted to capture urban characteristics using a variety of variables (see Table 1 in Bhatta et al. (2010) and Table 1 in Siedentop and Fina (2010)). We follow the theory and framework for urban data specifications constructed in previous studies. Here, we explain the reason for the choice of determinant variables with reference to the previous literature.

First, we use DENS as the degree of agglomeration in metropolitan areas. According to Melo et al. (2009) and Uchida and Nelson (2010), population density is a key variable for evaluating urban agglomeration. Fritsch and Mueller (2008) note, "One of these variables is population density or degree of agglomeration". Thus, we apply DENS as a proxy variable for urban agglomeration.

Next, we apply COMM as the degree of urban sprawl. Wolman et al. (2005) analyse urban sprawl by focusing on a commuting data variable. Holcombe and Williams (2010) state, "A most common complaint of sprawling development is that it lengthens commuting times". Thus, there is a strong relationship between commuting time and urban sprawl. Based on these studies, we use COMM as a proxy variable for urban sprawl.

It should be noted that the different methods of commuting could lead to differences in $\mathrm{CO}_{2}$ emissions. For example, transit-oriented development, which refers to the idea of integrating transit and land use by focusing development around transit stations, can achieve a good balance between urban 
sprawl and $\mathrm{CO}_{2}$ emissions reduction due to a high rate of public transportation usage (OECD, 2015). However, data on the utilization of public transportation are not available. Thus, it is difficult for us to investigate the methods of commuting in each metropolitan area. Based on this data limitation, this study used the degree of urban sprawl.

Finally, the CORE variable is used as the degree of compactness. In contrast to COMM, which evaluates urban sprawl by focusing on a specific area, CORE measures the degree of compactness using the population distribution. According to the OECD (2012), the population over the surface of urban land within a metropolitan area, which is the definition of CORE, can be introduced as a proxy variable for urban compactness.

\section{3-3. Determinants analysis}

To identify effective urban policies to mitigate climate change for each cluster and region, we employ regression analysis. That is, we regress $\mathrm{CO}_{2}$ emissions intensity on the three determinant factors (see Table 1) for each cluster. Therefore, we perform 5 estimations (i.e., 4 clusters + all observations). In addition, we allow heterogeneous effects of each determinant factor among regions because there is a high degree of diversity with regard to cultural and social backgrounds among the regions. We use the interaction terms of a regional dummy (i.e., $R$ ) and three determinant factors instead of the simple determinant factors. The specification for the regression is assumed to be as in the following equation (2):

$$
\begin{array}{r}
\text { INTENSITY }_{i j k t}=\alpha+\sum_{i} \beta_{0 i} \cdot R_{i} \cdot \text { DENS }_{i j k t}+\sum_{i} \beta_{1 i} \cdot R_{i} \cdot \operatorname{COMM}_{i j k t}+\sum_{i} \beta_{2 i} \cdot R_{i} \cdot \operatorname{CORE}_{i j k t}+\mu_{t}+ \\
\delta_{j}+\varepsilon_{i j k t} \cdot(2)
\end{array}
$$

The subscripts $i, j, k$ and $t$ denote region, country, city and time, respectively, whereas $\alpha$ and $\beta_{0 i}$, $\beta_{1 i}$, and $\beta_{2 i}(i=1, \ldots, 5)$ are parameters. Therefore, 16 parameters are estimated in each regression. The unobserved time- and country-specific effects are captured by $\mu_{t}$ and $\delta_{j}$, respectively. The idiosyncratic error term is expressed as $\varepsilon_{i j k t}$.

The country-specific effects capture the effects of countries' time-irrelevant characteristics such as geographic, climatic, social and cultural conditions. Additionally, the time-specific effects control for 
country-irrelevant time effects such as economic fluctuations throughout the world. We apply these two specific effects to control for the effects of country and time differences in our estimation.

Dynamic panel data analysis (e.g., generalized method of moments) is an alternative model for determinants analysis using panel data. However, dynamic panel data analysis needs to have a two-year lag for the estimation (Arellano \& Bond, 1991). Because our dataset covers only three years, it is difficult to establish a two-year lag for the estimation using a fixed effects model. However, the use of a fixed effects model that employs country- and time-specific effects is important to control for the characteristics of metropolitan areas in the determinants analysis. Thus, we select a regression model with a specific effects term based on the situation for our dataset and its relevance to our research objective. This aspect is a limitation of this study.

\section{Results}

\section{4-1. Determinants analysis of changes in urban $\mathrm{CO}_{2}$ intensity}

Table 2 presents the results of the determinants analysis using INTENSITY as the dependent variable. In addition to Table 2, we describe the results of the determinants analysis using $\mathrm{CO}_{2}$ per capita and GDP per capita as the dependent variables in Appendix 2 and Appendix 3, respectively. In these tables, we show the results of five models, including the entire sample (276 cities), using city data in each cluster. We use three determinant variables with a cross-term of regional dummy variables.

One advantage of the cross-term with regional dummies approach is the direct comparability of the coefficient score among regions with the same determinant variables. Therefore, the differences in the effects of the determinant variables on carbon intensity can be identified by comparing the coefficient values of the cross-terms. Furthermore, the combination of independent variables is the same in the five models (e.g., all-sample model, cluster 1 model). Therefore, we can also directly compare the coefficient scores among the models.

As shown in Table 2, the coefficient scores of the three determinant variables differ among the regions and cluster groups. The results indicate that the three determinant variables affect INTENSITY differently among the regional groups and clusters. It should be noted that we observed many cases in 
which the sign of the coefficient score is the opposite with regard to the results of the all-sample model and that of each cluster model. These results imply that the effects of the determinant variables on INTENSITY change when we consider the characteristics of urban $\mathrm{CO}_{2}$ emissions sources. This finding provides important evidence that urban policies that are based on empirical studies that do not consider urban $\mathrm{CO}_{2}$ emissions characteristics might be misleading with regard to urban $\mathrm{CO}_{2}$ mitigation.

Table 2 shows that all cross-terms between the three determinant variables and the U.S. dummy significantly affect INTENSITY. One interesting result is that the cross-term between CORE and the U.S. dummy positively affects INTENSITY in the all-sample model. This result implies that a decreasing concentration of the population in the core area contributes to reduced INTENSITY, regardless of the urban $\mathrm{CO}_{2}$ emissions sources in the U.S. The coefficient score of the cross-term between CORE and the U.S. dummy differs among the cluster models. The result of the cluster 2 model shows the largest coefficient score, and the result of cluster 4 is the smallest. Therefore, the expected INTENSITY reduction effect due to a CORE decline is stronger in cities in cluster 2 than the others.

$<$ Table 2 about here $>$

Additionally, the cross-term between the U.S. dummy and COMM showed the opposite coefficient sign in the all-sample model and the cluster 1 model. One interpretation of this result is that the main $\mathrm{CO}_{2}$ emissions source is the energy industry in the cluster 1 city group. The amount of $\mathrm{CO}_{2}$ emissions from the energy industry is usually directly related to the scale of electricity demand and the energy mix for power generation. However, this is not directly related to the urban structure, including the commuting zone, which may be one reason for the opposite coefficient sign between the all-sample and cluster 1 models.

Next, we discuss the other regional dummy results. The cross-term between DENS and the CL\&MX dummy has a significantly positive effect on INTENSITY in all cluster models except for cluster 4. In contrast to this result, the cross-term between CORE and CL\&MX has a significantly negative effect on INTENSITY in the cluster 2 and cluster 3 models. These results indicate that effective urban policies to decrease INTENSITY are decreased density and increased concentration for cities grouped in clusters 2 and 3 in Chile and Mexico. Detailed urban policy options will be discussed in the next section. 


\section{4-2. Urban policy options for $\mathrm{CO}_{2}$ emissions mitigation}

Next, we consider the determinants analysis results by focusing on two driving factors of INTENSITY (see Figure 2). Appendix 4 summarizes the determinants analysis results using INTENSITY, $\mathrm{CO}_{2}$ per capita, and GDP per capita as the dependent variables (detailed results are shown in Table 2 and in Appendix 2 and Appendix 3). As shown in Appendix 4, the significance levels and signs of the coefficient scores differ among the country dummies and cluster groups.

We can identify the most desirable combination of coefficient scores by referring to Appendix 4. If we observe the combinations in which the determinant variable negatively (positively) affects INTENSITY and $\mathrm{CO}_{2}$ per capita and positively (negatively) affects GDP per capita, then decreasing (increasing) the determinant variables decrease INTENSITY by decreasing $\mathrm{CO}_{2}$ per capita and increasing GDP per capita simultaneously. We explain this approach using the results of the cross-term between the three determinant variables and the U.S. dummy. Table 3 presents the desirable change in the determinant variables identified in Appendix 4. In Table 3, "Increase” shows that increasing the determinant variable score is a desirable way to decrease INTENSITY and $\mathrm{CO}_{2}$ per capita and to increase GDP per capita. In contrast, "Decrease" suggests that decreasing the determinant variable score is a desirable approach.

It is important to consider that the suggested urban policy should be consistent with managerial insights from urban planning. In other words, urban policy makers will not refer to a suggested urban policy if it will decrease the flexibility of land use and the attractiveness of the city. From an economic perspective, it is well known that policy options using market mechanisms are more flexible and efficient than restrictive policies (e.g., command and control) (Iwata and Managi, 2016). Based on this idea, we propose policy options that focus on market mechanisms such as property taxes.

$<$ Table 3 about here $>$

As shown in Table 3, an increase in DENS and a decrease in CORE are a desirable means of reducing INTENSITY. To achieve these changes to these determinant variables, property taxes are one effective urban policy option. According to Brueckner and Kim (2003) and Song and Zenou (2006), a decrease (increase) in property taxes promotes population inflow (outflow). Therefore, an increase in 
property taxes over an entire metropolitan area can be expected to increase the population density. In addition to this policy, further increasing property taxes in the core area would contribute to decreasing the population concentration in this area. The combination of these two urban policy options is proposed based on the results of the determinants analysis.

However, we should note that the desirable determinant variable change differs between the allsample model and cluster 2. Therefore, the above policy options would be helpful for cities in the U.S. except for those in cluster 2 . This differing trend provides important evidence regarding the importance of developing urban climate policy while considering city characteristics because an urban policy that refers only to the all-sample results would have undesirable effects in cities with unique characteristics with regard to urban climate change mitigation. One advantage of determinants analysis in combination with cluster analysis is the ability to identify desirable urban policy options for cities that have different trends from the entire sample.

As shown in Table 3, decreasing both DENS and COMM produces a desirable variable change to decrease INTENSITY and $\mathrm{CO}_{2}$ per capita with increased GDP per capita in cluster 2. One policy option for decreasing the commuting area is land use regulations. Banzhaf and Lavery (2010) note that an increase in land (split) taxes exerts a more constraining influence on city size (urban sprawl) than an increase in property taxes. Iwata and Managi (2016) clarify that property taxes and land use regulations clearly affect population density. To restrict suburban living by applying these land tax and land use regulations, governments can create urban commuting zones.

Finally, cluster 3 shows that the combination that produces the most desirable determinant change involves increasing COMM and decreasing CORE. Because the main $\mathrm{CO}_{2}$ emissions source in cluster 3 is the transport sector, the highly concentrated core areas in cities in this cluster tend to lead to traffic congestion due to the prevalence of commuting by private car. According to INRIX (2017), New York and San Francisco, which are categorized as cities in cluster 3, have been identified as the third and fourth worst cities in the world for traffic congestion. This result provides further evidence that cities in cluster 3 tend to suffer from traffic congestion. 
Based on this information, we can suggest an expansion of public transportation services in order to expand the commuting zone. In addition to this urban policy, increasing the property taxes in core areas would contribute to decreasing the population concentration in those areas. An alternative urban policy to decrease traffic congestion is to increase the incentives to use public transportation, such as by introducing additional customer services (Zhang et al, 2014).

\section{Conclusions}

This study examined the determinant factors that contribute to changes in urban $\mathrm{CO}_{2}$ emissions intensity by considering the city characteristics of the main $\mathrm{CO}_{2}$ emissions sources. We use data from 276 metropolitan areas in 26 countries from 2000, 2005, and 2008. This study divides the sample into five regional groups and four clusters based on $\mathrm{CO}_{2}$ emissions sources in order to control for the specific characteristics of metropolitan areas. In this study, a research framework was proposed that combined three approaches: decomposition analysis, cluster analysis, and determinants analysis.

We find that the determinants of the driving factors of changes in urban $\mathrm{CO}_{2}$ emissions differ by city cluster type and region. Our estimation results indicate that a decreasing concentration of the population in the core area contributes to reduced $\mathrm{CO}_{2}$ emissions per capita regardless of urban $\mathrm{CO}_{2}$ emissions sources in the U.S. On the other hand, there are many cases in which the sign of the coefficient is the opposite with regard to the results of each cluster sample and the results of all-sample model.

These findings indicate that urban policies based on empirical analyses that do not consider the portfolio of urban $\mathrm{CO}_{2}$ emissions sources might be misleading with regard to urban $\mathrm{CO}_{2}$ mitigation. This result implies that we can implement better urban policies to improve each factor by considering the characteristics of each city type.

Currently, many local governments have designed environmental policies to reduce urban $\mathrm{CO}_{2}$ emissions. The novel contribution of the present study is the development of a research framework to identify the determinants of changes to urban $\mathrm{CO}_{2}$ emissions. The research framework and the application of the decomposition and econometric analyses for urban $\mathrm{CO}_{2}$ emissions changes may be helpful in 
evaluating the determinants of urban $\mathrm{CO}_{2}$ emissions, which can contribute to building effective urban planning strategies and environmental policies.

Further research is needed to investigate the following three aspects. First, to reduce urban $\mathrm{CO}_{2}$ emissions, it is useful to identify the appropriate partnerships between local and national governments because both urban planning by both levels of government influences urban $\mathrm{CO}_{2}$ emissions. This argument is similar to that regarding the issue of effective carbon rates (OECD, 2016). Second, it is necessary to focus on different pollutants (e.g., a determinants analysis of urban air pollution substances) and to provide key information for urban air pollution management in order to protect human health (Zhang et al., 2017). Third, it is important to consider new technologies and people's preferences (e.g., smart cities and a sharing economy) for desirable urban policy designs (Cohen and Muñoz, 2016).

\section{References}

Ahmad, S., Baiocchi, G and Creutzig, F. (2015) $\mathrm{CO}_{2}$ emissions from direct energy use of urban households in India. Environmental Science and Technology, 49, 11312-11320.

Ali, H. S., Abdul-Rahim, AS and Ribadu, M. B. (2017) Urbanization and carbon dioxide emissions in Singapore: evidence from the ARDL approach. Environmental Science and Pollution Research, 24(2), 1967-1974.

Arellano, M., Bond, S. (1991) Some Tests of Specification for Panel Data: Monte Carlo Evidence and an Application to Employment Equations. The Review of Economic Studies, 58(2), 277-297.

Banzhaf, H.S., Lavery, N. (2010) Can the land tax help curb urban sprawl? Evidence from growth patterns in Pennsylvania. Journal of Urban Economics, 67, 169-179.

Bhatta, B., Saraswati, S., Bandyopadhyay, D. (2010) Urban sprawl measurement from remote sensing data. Applied Geography, 30, 731-740.

Brueckner, J., Kim, H.A. (2003) Urban Sprawl and the Property Tax. International Tax and Public Finance, 10, 5-23.

Broto, V.C., Bulkeley, H. (2013). A survey of urban climate change experiments in 100 cities. Global Environmental Change, 23(1), 92-102. 
Broto, V. C. (2017) Urban Governance and the Politics of Climate change. World Development, 93, 1-15.

Chévez, P., Barbero, D., Martini, I., Discoli, C. (2017) Application of the k-means clustering method for the detection and analysis of areas of homogeneous residential electricity consumption at the Great La Plata region, Buenos Aires, Argentina. Sustainable Cities and Society, 32, 115-129.

Cohen, B., Muñoz, P. (2016). Sharing cities and sustainable consumption and production: towards an integrated framework. Journal of Cleaner Production, 134(A), 87-97.

Damsø, T., Kjær, T., Christensen, T.B. (2016) Local climate action plans in climate change mitigation examining the case of Denmark. Energy Policy, 89, 74-83.

Davoudi, S., Crawford, J., Mehmood, A. (Eds.), 2010. Planning for climate change: Strategies for mitigation and adaptation for spatial planners. Earthscan, London.

Dong, B., Wang, F., Guo, Y. (2016). The global EKCs. International Review of Economics \& Finance, 43, $210-221$.

Fragkias, M., Lobo, J., Strumsky, D., Seto, K.C. (2013) Does size matter? Scaling of CO2 emissions and U.S. urban areas. PLoS ONE, 8(6): e64727. doi:10.1371/journal.pone.0064727

Fang , C., Wqang, W. and Li, G. (2015) Changing urban forms and carbon dioxide emissions in China: A case study of 30 provincial capital cities, Applied Energy, 158, 519-531.

Fritsch, M., Mueller, P.(2008) The effect of new business formation on regional development over time: the case of Germany. Small Business Economics, 30(1), 15-29.

Fujii, H., Managi, S. (2013) Which industry is greener? An empirical study of nine industries in OECD countries. Energy Policy, 57, 381-388.

Fujii, H., Managi, S. (2016a). An evaluation of inclusive capital stock for urban planning. Ecosystem Health and Sustainability, 2(10):e01243. doi:10.1002/ehs2.1243.

Fujii, H., Assaf, A.G., Managi, S., Matousek, R. (2016b). Did the financial crisis affect environmental efficiency? Evidence from the Japanese manufacturing sector. Environmental Economics and Policy Studies, 18(2), 159-168.

Glaeser, E. L. and Kahn, M. E. (2010) The greenness of cities: carbon dioxide emissions and urban development. Journal of Urban Economics, 67, 404-418.

Hendrickson, T.P., Nikolic, M., Rakas, J. (2016) Selecting climate change mitigation strategies in urban areas through life cycle perspectives. Journal of Cleaner Production, 135, 1129-1137. 
Holcombe, R.G., DeEdgra W. Williams (2010) Urban Sprawl and Transportation Externalities. The Review of Regional Studies, 40(3), 257-273.

INRIX (2017) INRIX Global Traffic Scorecard. INRIX. http://inrix.com/scorecard/

Iwata, K., Managi, S. (2016) Can land use regulations and taxes help mitigate vehicular $\mathrm{CO}_{2}$ emissions? An empirical study of Japanese cities. Urban Policy and Research, 34(4), 356-372.

Lee, T., Painter, M. (2015) Comprehensive local climate policy: The role of urban governance. Urban Climate, 14, 566-577.

Li, C., Sun, L., Jia, J., Cai, Y., Wang, X. (2016) Risk assessment of water pollution sources based on an integrated k-means clustering and set pair analysis method in the region of Shiyan, China. Science of The Total Environment, 557-558, 307-316.

Liddle, B. (2014) Impact of population, age structure, and urbanization on carbon emissions/energy consumption: evidence from macro-level, cross-country analysis. Population and Environment, 35(3), 286-304.

Makido, Y., Dhakal, S. and Yamagata, Y. (2012) Relationship between urban form and $\mathrm{CO}_{2}$ emissions: Evidence from fifty Japanese cities. Urban Climate, 2, 55-67.

Marcotullio, P., Sarzynski, A., Albrecht, J. and Schulz, H. (2012) The geography of urban greenhouse gas emissions in Asia: A regional analysis. Global Environmental Change, 22, 944-958.

Marcotullio, P. J., Sarzynski, A., Albrecht, J. and Shulz, N. (2014) A top-down regional assessment of urban greenhouse gas emissions in Europe. AMBIO, 43(7), 957-968.

McDonald, R.I., Green, P., Balk, D., Fekete, B.M., Revenga, C., Todd, M., Montgomery, M. (2011) Urban growth, climate change, and freshwater availability. Proceedings of the National Academy of Sciences of the United States of America, 108(5), 6312-6317.

Meng, L. and Fuang, B. (2017) Shaping the relationship between economic development and carbon dioxide emissions at the local level: Evidence from spatial econometric models. Environmental and Resource Economics, forthcoming. doi: 10.1007/s10640-017-0139-2

Meng, J., Mi, Z., Yang, H., Shan, Y., Guan, D., Liu, J. (2017) The consumption-based black carbon emissions of China's megacities. Journal of Cleaner Production, forthcoming. doi: 10.1016/j.jclepro.2017.02.185 
Melo, P.C., Graham, D.J., Noland, R.B. (2009) A meta-analysis of estimates of urban agglomeration economies. Regional Science and Urban Economics, 39, 332-342.

Mi, ZF., Wei, YM., He, CQ., Li, HN., Yuan, X.C., Liao, H. (2017) Regional efforts to mitigate climate change in China: a multi-criteria assessment approach. Mitigation and Adaptation Strategies for Global Change, 22(1), 45-66.

Newman, P. W. G. and Kenworthy, J. R. (1989) Gasoline consumption and cities. Journal of the American Planning Association, 55(1), 24-37.

Norman, J., MacLean, H. L. and Kennedy, C. A. (2006) Comparing high and low residential density: Lifecycle analysis of energy use and greenhouse gas emissions. Journal of Urban Planning and Development, 132(1), 10-21.

OECD (2012). Redefining "Urban": A New Way to Measure Metropolitan Areas. OECD publishing, Paris. doi: 10.1787/9789264174108-en.

OECD (2012) Compact city policies: A comparative assessment. OECD publishing, Paris. http://www.oecd.org/greengrowth/compact-city-policies-9789264167865-en.htm

OECD (2013) OECD Regions at a Glance 2013. OECD Publishing, Paris. http://dx.doi.org/10.1787/reg_glance-2013-en

OECD (2014) Cities and climate change: National governments enabling local action. OECD Publishing, Paris. http://www.oecd.org/env/cc/Cities-and-climate-change-2014-Policy-Perspectives-Final-web.pdf

OECD (2015) Aligning Policies for a Low-carbon Economy. OECD Publishing, Paris. https://www.oecd.org/environment/Aligning-Policies-for-a-Low-carbon-Economy.pdf

OECD (2016) Effective carbon rates: Pricing $\mathrm{CO}_{2}$ through taxes and emissions trading scheme, OECD Publishing, Paris.

Reis, M. (2014). 5 U.S. Cities Using Technology To Become Smart And Connected. Forbes. https://www.forbes.com/sites/ptc/2014/08/15/5-u-s-cities-using-technology-to-become-smart-andconnected/\#6a5b27f27212.

Rosenzweig, C., Solecki, W., Hammer, S.A., Mehrotra, S. (2010) Cities lead the way in climate-change action. Nature, 467, 909-911.

Siedentop, S., Fina, S. (2010) Monitoring urban sprawl in Germany: towards a GIS-based measurement and assessment approach. Journal of Land Use Science, 5(2), 73-104. 
Song, Y., Zenou, Y. (2006) Property tax and urban sprawl: Theory and implications for US cities. Journal of Urban Economics, 60, 519-534.

Uchida, H., Andrew, N. (2010) Agglomeration index: Towards a new measure of urban concentration, Working paper / World Institute for Development Economics Research, No. 2010,29, ISBN 978-929230-264-1.

UNEP (2012) Cities and Carbon Finance: A feasibility study on an Urban CDM. Nairobi.

UNFCCC (2015) Non-paper. Note by the Co-Chairs. the Ad Hoc Working Group on the Durban Platform for Enhanced Action, ADP.2015.8.InformalNote, 5 October 2015, http://unfccc.int/resource/docs/2015/adp2/eng/8infnot.pdf

Viguié, V., Hallegatte, S. (2012) Trade-offs and synergies in urban climate policies. Nature Climate Change, 2, 334-337. doi:10.1038/nclimate1434.

Wamsler, C., Brink, E., Rivera, C. (2013) Planning for climate change in urban areas: from theory to practice. Journal of Cleaner Production, 50, 68-81.

Wang, Z. and Xinyue Y. (2016). Re-examining environmental Kuznets curve for China’s city-level carbon dioxide $\left(\mathrm{CO}_{2}\right)$ emissions. Spatial Statistics, forthcoming. doi.org/10.1016/j.spasta.2016.09.005.

Wolman, H., Galster, G., Hanson, R., Ratcliffe, M., Furdell, K., Sarzynski, A. (2005) The Fundamental Challenge in Measuring Sprawl: Which Land Should Be Considered? The Professional Geographer, 57(1), 94-105.

Zhang, Z., Fujii, H., Managi, S. (2014). How does commuting behavior change due to incentives? An empirical study of the Beijing subway system. Transportation Research Part F: Traffic Psychology and Behaviour, 24, 17-26.

Zhang, Q., Jiang, X., Tong, D., Davis, S.J., Zhao, H., Geng, G., Feng, T., Zheng, B., Lu, Z., Streets, D.G., Ni, R., Brauer, M., van Donkelaar, A., Martin, R.V., Huo, H., Liu, Z., Pan, D.,Kan, H., Yan, Y., Lin, J., He, K., Guan, D. (2017) Transboundary health impacts of transported global air pollution and international trade. Nature, 543, 705-709.

Zhang, C. and Lin, Y. (2012) Panel estimation for urbanization, energy consumption and $\mathrm{CO}_{2}$ emissions: A regional analysis in China. Energy Policy, 49, .488-498. 
Table 1. Data description

\begin{tabular}{|c|c|c|c|c|c|}
\hline & Variable (code) & Definition & unit & $\begin{array}{l}\text { Mean } \\
\text { value }\end{array}$ & Std. dev. \\
\hline \multirow{3}{*}{$\begin{array}{c}\mathrm{CO}_{2} \\
\text { emissions } \\
\text { and driving } \\
\text { factors }\end{array}$} & $\begin{array}{l}\mathrm{CO}_{2} \text { emissions per } \\
\text { capita }\left(\mathrm{CO}_{2} \text { per }\right)\end{array}$ & $\begin{array}{c}\mathrm{CO}_{2} \text { emissions }\left(\mathrm{CO}_{2}\right) \text { divided } \\
\text { by population }\end{array}$ & $\begin{array}{l}\text { Tons } \\
\mathrm{CO}_{2} / \\
\text { person }\end{array}$ & 10.63 & 7.60 \\
\hline & $\begin{array}{l}\text { GDP per capita } \\
\text { (GDPper) }\end{array}$ & $\begin{array}{l}\text { GDP of metropolitan area } \\
\text { divided by population }\end{array}$ & US \$ & 37,226 & 15,389 \\
\hline & $\begin{array}{l}\mathrm{CO}_{2} \text { emissions per } \\
\text { GDP (INTENSITY) }\end{array}$ & $\begin{array}{l}\mathrm{CO}_{2} \text { emissions divided by } \\
\text { GDP of metropolitan area }\end{array}$ & $\begin{array}{c}\text { Tons } \\
\mathrm{CO}_{2} / \\
\text { million } \\
\text { US \$ }\end{array}$ & 284.37 & 171.05 \\
\hline \multirow{6}{*}{$\begin{array}{l}\text { Data for } \\
\text { cluster } \\
\text { analysis }\end{array}$} & $\begin{array}{l}\mathrm{CO}_{2} \text { emissions from } \\
\text { energy industry }\left(\mathrm{CO}_{2}^{\text {ene }}\right)\end{array}$ & $\begin{array}{l}\mathrm{CO}_{2} \text { emissions from } \\
\text { energy industry }\end{array}$ & $\begin{array}{l}\text { Million } \\
\text { tons } \mathrm{CO}_{2}\end{array}$ & 4.62 & 7.89 \\
\hline & $\begin{array}{l}\mathrm{CO}_{2} \text { emissions from } \\
\text { transport }\left(\mathrm{CO}_{2}^{t r}\right)\end{array}$ & $\begin{array}{l}\mathrm{CO}_{2} \text { emissions from } \\
\text { transport sector }\end{array}$ & $\begin{array}{l}\text { Million } \\
\text { tons } \mathrm{CO}_{2}\end{array}$ & 5.84 & 12.75 \\
\hline & $\begin{array}{l}\mathrm{CO}_{2} \text { emissions from } \\
\text { other sectors }\left(\mathrm{CO}_{2}^{\text {other }}\right)\end{array}$ & $\mathrm{CO}_{2}-\left(\mathrm{CO}_{2}^{e n e}+\mathrm{CO}_{2}^{t r}\right)$ & $\begin{array}{l}\text { Million } \\
\text { tons } \mathrm{CO}_{2}\end{array}$ & 10.01 & 18.64 \\
\hline & $\begin{array}{l}\text { Share of } \mathrm{CO}_{2} \text { emissions } \\
\text { from energy industry }\end{array}$ & $\mathrm{CO}_{2}^{\text {ene }} / \mathrm{CO}_{2}$ & $\%$ & $21 \%$ & $23 \%$ \\
\hline & $\begin{array}{l}\text { Share of } \mathrm{CO}_{2} \text { emissions } \\
\text { from transport }\end{array}$ & $\mathrm{CO}_{2}^{t r} / \mathrm{CO}_{2}$ & $\%$ & $29 \%$ & $13 \%$ \\
\hline & $\begin{array}{l}\text { Share of } \mathrm{CO}_{2} \text { emissions } \\
\text { from other sectors }\end{array}$ & $\mathrm{CO}_{2}^{\text {other }} / \mathrm{CO}_{2}$ & $\%$ & $50 \%$ & $18 \%$ \\
\hline \multirow{3}{*}{$\begin{array}{l}\text { Determinant } \\
\text { factors }\end{array}$} & $\begin{array}{l}\text { Population density of } \\
\text { metropolitan area } \\
\text { (DENS) }\end{array}$ & Population / metropolitan area & $\underset{\mathrm{km}^{2}}{\text { persons / }}$ & 670.94 & 740.27 \\
\hline & $\begin{array}{l}\text { Commuting zone share } \\
\text { (COMM) }\end{array}$ & $\begin{array}{l}\text { Commuting zone land share } \\
\text { over metropolitan area }\end{array}$ & $\%$ & 60.38 & 29.25 \\
\hline & $\begin{array}{l}\text { Concentration of } \\
\text { population in the core } \\
\text { (CORE) }\end{array}$ & $\begin{array}{l}\text { Share of population living in } \\
\text { the core area over the total } \\
\text { metropolitan population }\end{array}$ & $\%$ & 75.40 & 17.58 \\
\hline
\end{tabular}

Source: Figure created by author using metropolitan area data from OECD.stat (OECD, 2013)

Note 1: Monetary data are deflated year 2010 prices.

Note 2: The energy sector includes public electricity, heat production, and other energy industries. The transport sector includes road, rail, and ground transportation. The "other" sector includes agriculture, manufacturing, services, and residential sectors (OECD, 2013).

Note 3: The core area and commuting zone are identified by the OECD (2013). The identification flow and detailed explanations are described in “Annex A: Defining regions and functional urban areas” and Figure A.5. 
Table 2. Results of determinants analysis (dependent variable is INTENSITY [ $\left.=\mathrm{CO}_{2} / \mathrm{GDP}\right]$ )

\begin{tabular}{|c|c|c|c|c|c|}
\hline VARIABLES & All sample & Cluster 1 & Cluster 2 & Cluster 3 & Cluster 4 \\
\hline AU\&CA $\times$ DENS & $-0.000729 * * *$ & 0.00258 & $0.000196 * * *$ & N.A. & $0.0186^{* * *}$ \\
\hline AU\&CA $\times C O M M$ & $-0.0101 * * *$ & $0.146^{* * *}$ & 0.000789 & N.A. & $-0.235^{* * *}$ \\
\hline AU\&CA $\times$ CORE & -0.00179 & $0.376^{* * *}$ & 0.000811 & N.A. & $0.267 * * *$ \\
\hline CL\&MX $\times$ DENS & $7.70 \mathrm{e}-06^{* * *}$ & $0.000293^{* * *}$ & $1.31 \mathrm{e}-05^{* * *}$ & $2.57 e-05^{* * *}$ & 0.000293 \\
\hline CL\&MX×COMM & $0.000266^{*}$ & $0.0134^{* * *}$ & -0.000560 & $-6.24 \mathrm{e}-05^{* * *}$ & 0.00873 \\
\hline CL\&MX $\times$ CORE & $-0.00425^{* * *}$ & $0.0243^{* * *}$ & $-0.0111 *$ & $-0.00654^{* * *}$ & -0.00288 \\
\hline EU×DENS & $-6.61 \mathrm{e}-05^{*}$ & $-0.000192 * * *$ & $1.15 \mathrm{e}-05$ & $1.98 \mathrm{e}-05$ & 5.71e-05 \\
\hline $\mathrm{EU} \times \mathrm{COMM}$ & $-0.00511^{* * *}$ & $-0.00844^{* * *}$ & $-0.00187 * * *$ & -0.000531 & -0.00458 \\
\hline $\mathrm{EU} \times \mathrm{CORE}$ & $-0.00146^{*}$ & -0.00274 & -0.00126 & 0.00112 & $0.00293^{* * *}$ \\
\hline JP\&KR $\times$ DENS & $3.48 \mathrm{e}-05^{* * *}$ & $-4.13 e-05$ & 7.05e-06 & N.A. & $-6.59 \mathrm{e}-05 * * *$ \\
\hline $\mathrm{JP} \& \mathrm{KR} \times \mathrm{COMM}$ & -0.00244 & $-0.00498 *$ & $0.000997^{* *}$ & N.A. & $-0.00117 * * *$ \\
\hline $\mathrm{JP} \& \mathrm{KR} \times \mathrm{CORE}$ & $-0.00484 * *$ & -0.00416 & 0.00151 & N.A. & $0.00198^{* * *}$ \\
\hline US $\times$ DENS & $-0.000122^{* * *}$ & $-9.26 \mathrm{e}-05^{* * *}$ & $0.000215^{* * *}$ & $-4.33 \mathrm{e}-06^{* * *}$ & $-0.000232 * * *$ \\
\hline US $\times$ COMM & $-5.83 \mathrm{e}-05^{* * *}$ & $0.00182^{* * *}$ & $0.000670^{* * *}$ & $-0.000664 * * *$ & $-0.00116^{* * *}$ \\
\hline $\mathrm{US} \times \mathrm{CORE}$ & $0.000691^{* * *}$ & $0.00102^{* * *}$ & $0.00241^{* * *}$ & $0.000841^{* * *}$ & $0.000134^{* * *}$ \\
\hline 2005 year dummy & $-0.0258 * * *$ & -0.0228 & $-0.0259 * * *$ & $-0.0220 * * *$ & $-0.0331^{* *}$ \\
\hline 2008 year dummy & $-0.0488 * * *$ & $-0.0588 *$ & $-0.0447^{* * *}$ & $-0.0379 * * *$ & $-0.0594 * * *$ \\
\hline Constant & $1.426^{* *}$ & $-2.258 * * *$ & 0.0363 & 0.0563 & $0.162^{* * *}$ \\
\hline Observations & 828 & 162 & 291 & 180 & 195 \\
\hline R-squared & 0.292 & 0.640 & 0.737 & 0.474 & 0.512 \\
\hline
\end{tabular}

Note $1: *$ denotes significance at $10 \%$ level, ${ }^{* *}$ denotes significance at $5 \%$ level, $* * *$ denotes significance at $1 \%$ level.

Note 2: "N.A." indicates that there is no sample selected, as in cluster 3 in the AU\&CA and JP\&KR region groups. 
Table 3. Desirable determinant variable changes and policy options for cities in the U.S.

\begin{tabular}{|l|c|c|c|c|}
\hline & DENS & COMM & CORE & \multicolumn{2}{c|}{\begin{tabular}{c} 
Desirable urban policy option \\
\hline All
\end{tabular}} & Increase & N.A. & Decrease & $\begin{array}{l}\text {-Decrease property taxes for metropolitan area } \\
\text {-Increase property taxes for core area }\end{array}$ \\
\hline Cluster 1 & N.A. & N.A. & N.A. & N.A. \\
\hline Cluster 2 & Decrease & Decrease & N.A. & $\begin{array}{l}\text {-Increase property taxes for metropolitan area } \\
\text {-Land use policy for suburban area }\end{array}$ \\
\hline Cluster 3 & N.A. & Increase & Decrease & $\begin{array}{l}\text {-Expand the public transportation area } \\
\text {-Increase property taxes for core area }\end{array}$ \\
\hline Cluster 4 & N.A. & N.A. & N.A. & N.A. \\
\hline
\end{tabular}

Note: "Increase" indicates that the determinant variable negatively affects INTENSITY and $\mathrm{CO}_{2}$ per capita and positively affects GDP per capita. "Decrease" indicates that the determinant variable positively affects INTENSITY and $\mathrm{CO}_{2}$ per capita and negatively affects GDP per capita. "N.A." indicates that the coefficient scores of the determinant variable do not observe the above combination. 


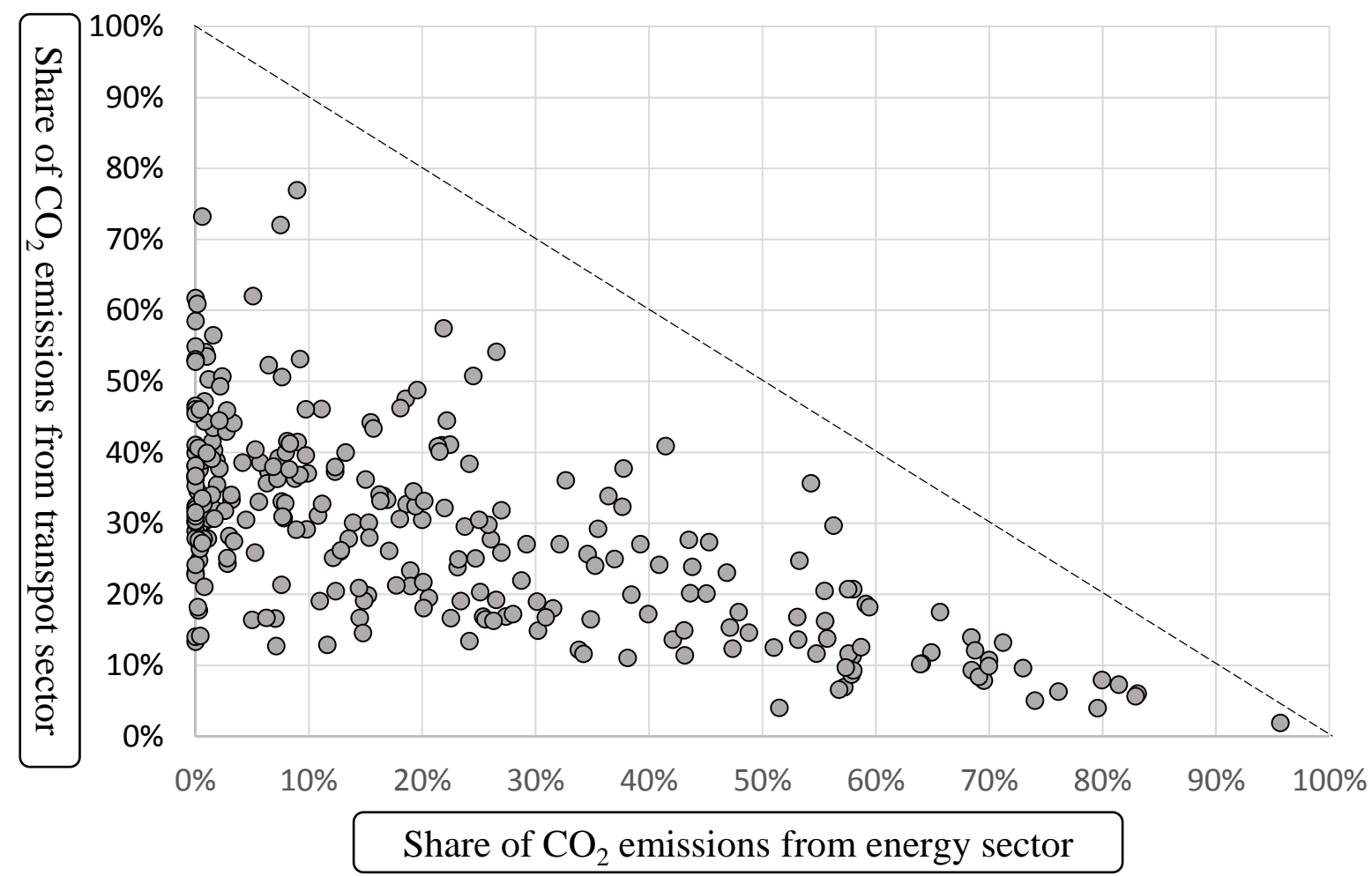

Figure 1. Scatterplot of $\mathrm{CO}_{2}$ emissions share in energy and transport sectors in 2008 Source: Figure created by author using metropolitan area data from the OECD.stat database 


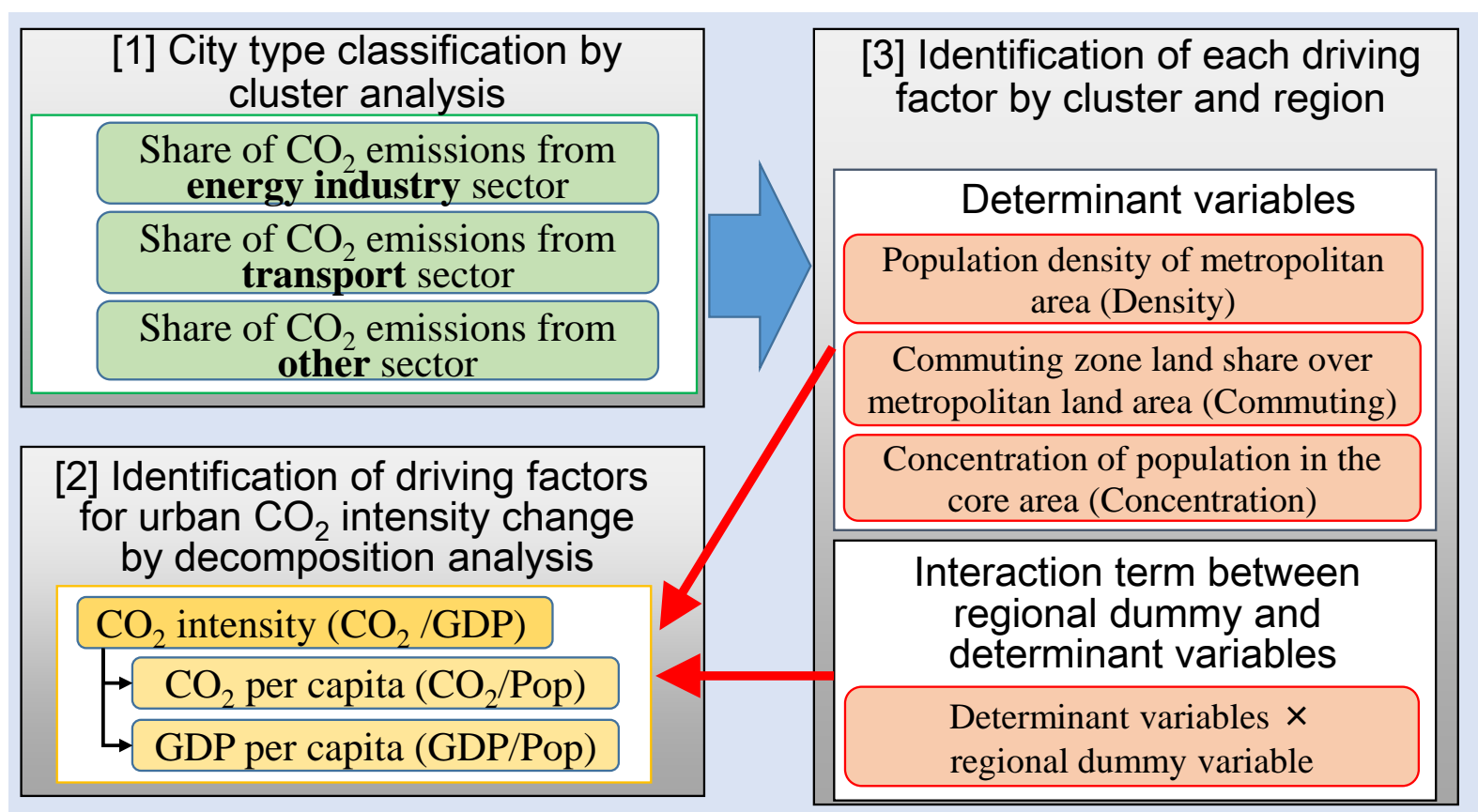

Figure 2. Research framework of this study 


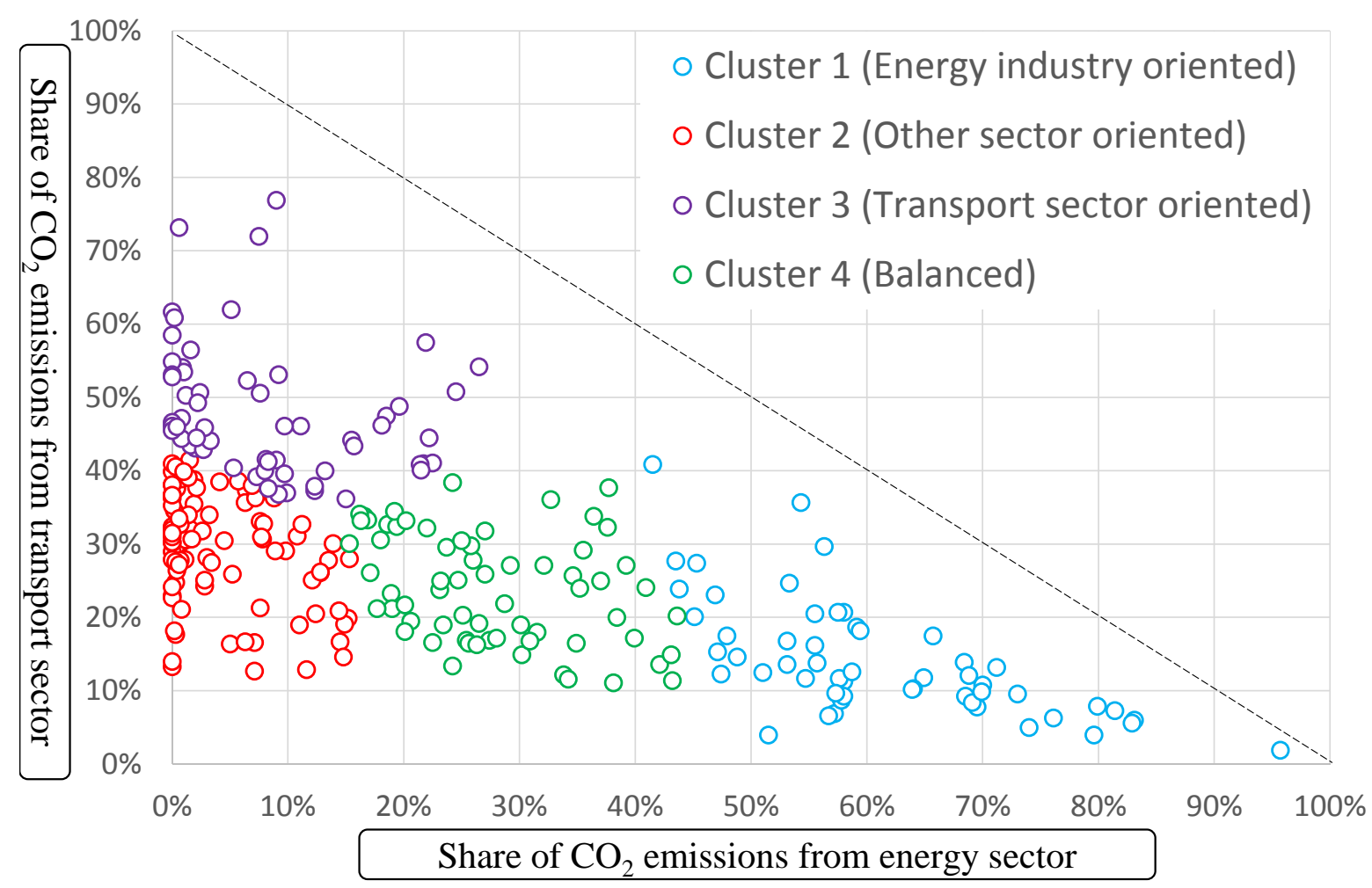

Figure 3. Results of cluster analysis for the share of $\mathrm{CO}_{2}$ emissions using year 2008 data 
Appendix 1-1. Metropolitan area names and region groups

\begin{tabular}{|c|c|c|c|c|c|c|c|}
\hline Metropolitan area name & Country & Country & Group & Metropolitan area name & Cluster & Country & Group \\
\hline Sydney & 2 & Australia & AU\&CA & Sapporo & 2 & Japan & JP\&KR \\
\hline Melbourne & 2 & Australia & AU\&CA & Sendai & 2 & Japan & JP\&KR \\
\hline Brisbane & 4 & Australia & AU\&CA & Niigata & 2 & Japan & JP\&KR \\
\hline Perth & 2 & Australia & AU\&CA & Toyama & 1 & Japan & JP\&KR \\
\hline Adelaide & 2 & Australia & AU\&CA & Nagano & 2 & Japan & JP\&KR \\
\hline Gold Coast-Tweed Heads & 2 & Australia & AU\&CA & Kanazawa & 2 & Japan & JP\&KR \\
\hline Edmonton & 1 & Canada & AU\&CA & Utsunomiya & 2 & Japan & JP\&KR \\
\hline Calgary & 2 & Canada & AU\&CA & Maebashi & 4 & Japan & JP\&KR \\
\hline Winnipeg & 2 & Canada & AU\&CA & Mito & 2 & Japan & JP\&KR \\
\hline Vancouver & 2 & Canada & AU\&CA & Tokyo & 4 & Japan & JP\&KR \\
\hline Quebec & 2 & Canada & AU\&CA & Kofu & 2 & Japan & JP\&KR \\
\hline Montreal & 2 & Canada & AU\&CA & Nagoya & 4 & Japan & JP\&KR \\
\hline Ottawa-Gatineau & 2 & Canada & AU\&CA & Numazu & 2 & Japan & JP\&KR \\
\hline Toronto & 2 & Canada & AU\&CA & Osaka & 4 & Japan & JP\&KR \\
\hline Hamilton & 1 & Canada & AU\&CA & Shizuoka & 2 & Japan & JP\&KR \\
\hline Valparaíso & 2 & Chile & CL\&MX & Anjo & 1 & Japan & JP\&KR \\
\hline Santiago & 2 & Chile & CL\&MX & Yokkaichi & 1 & Japan & JP\&KR \\
\hline Concepción & 4 & Chile & CL\&MX & Himeji & 1 & Japan & JP\&KR \\
\hline Mexicali & 1 & Mexico & CL\&MX & Toyohashi & 2 & Japan & JP\&KR \\
\hline Tijuana & 2 & Mexico & CL\&MX & Hamamatsu & 2 & Japan & JP\&KR \\
\hline Juárez & 1 & Mexico & CL\&MX & Okayama & 2 & Japan & JP\&KR \\
\hline Hermosillo & 1 & Mexico & CL\&MX & Kurashiki & 4 & Japan & JP\&KR \\
\hline Chihuahua & 1 & Mexico & CL\&MX & Fukuyama & 2 & Japan & JP\&KR \\
\hline Reynosa & 1 & Mexico & CL\&MX & Hiroshima & 2 & Japan & JP\&KR \\
\hline Monterrey & 4 & Mexico & CL\&MX & Takamatsu & 2 & Japan & JP\&KR \\
\hline Torreón & 3 & Mexico & CL\&MX & Wakayama & 1 & Japan & JP\&KR \\
\hline Saltillo & 2 & Mexico & CL\&MX & Tokushima & 1 & Japan & JP\&KR \\
\hline Culiacán & 1 & Mexico & CL\&MX & Kitakyushu & 1 & Japan & JP\&KR \\
\hline Durango & 2 & Mexico & CL\&MX & Matsuyama & 2 & Japan & JP\&KR \\
\hline Tampico & 1 & Mexico & CL\&MX & Fukuoka & 2 & Japan & JP\&KR \\
\hline San Luis Potosí & 3 & Mexico & CL\&MX & Kochi & 4 & Japan & JP\&KR \\
\hline Aguascalientes & 3 & Mexico & CL\&MX & Oita & 1 & Japan & JP\&KR \\
\hline Benito Juárez & 3 & Mexico & CL\&MX & Kumamoto & 2 & Japan & JP\&KR \\
\hline León & 2 & Mexico & CL\&MX & Nagasaki & 2 & Japan & JP\&KR \\
\hline Mérida & 3 & Mexico & CL\&MX & Kagoshima & 2 & Japan & JP\&KR \\
\hline Guadalajara & 2 & Mexico & CL\&MX & Naha & 1 & Japan & JP\&KR \\
\hline Irapuato & 2 & Mexico & CL\&MX & Seoul Incheon & 2 & Korea & JP\&KR \\
\hline Querétaro & 4 & Mexico & CL\&MX & Cheongju & 4 & Korea & JP\&KR \\
\hline Celaya & 3 & Mexico & CL\&MX & Daejeon & 2 & Korea & JP\&KR \\
\hline Pachuca de Soto & 3 & Mexico & CL\&MX & Pohang & 2 & Korea & JP\&KR \\
\hline Morelia & 3 & Mexico & CL\&MX & Daegu & 2 & Korea & JP\&KR \\
\hline Mexico City & 3 & Mexico & CL\&MX & Jeonju & 2 & Korea & JP\&KR \\
\hline Xalapa & 3 & Mexico & CL\&MX & Ulsan & 1 & Korea & JP\&KR \\
\hline Toluca & 3 & Mexico & CL\&MX & Busan & 2 & Korea & JP\&KR \\
\hline Veracruz & 3 & Mexico & CL\&MX & Changwon & 1 & Korea & JP\&KR \\
\hline Puebla & 3 & Mexico & CL\&MX & Gwangju & 2 & Korea & JP\&KR \\
\hline Cuernavaca & 2 & Mexico & CL\&MX & & & & \\
\hline Centro & 3 & Mexico & CL\&MX & & & & \\
\hline Oaxaca de Juárez & 3 & Mexico & CL\&MX & & & & \\
\hline Acapulco de Juárez & 3 & Mexico & CL\&MX & & & & \\
\hline Tuxtla Gutiérrez & 3 & Mexico & CL\&MX & & & & \\
\hline
\end{tabular}


Appendix 1-2. Metropolitan area names in Europe region (EU)

\begin{tabular}{|c|c|c|c|c|c|}
\hline Metropolitan area name & Cluster & Country & Metropolitan area name & Cluster & Country \\
\hline Vienna & 4 & Austria & Brussels & 2 & Belgium \\
\hline Graz & 4 & Austria & Antwerp & 2 & Belgium \\
\hline Linz & 2 & Austria & Ghent & 1 & Belgium \\
\hline Prague & 4 & Czech Republic & Liege & 4 & Belgium \\
\hline Brno & 2 & Czech Republic & Athens & 3 & Greece \\
\hline Ostrava & 2 & Czech Republic & Thessalonica & 2 & Greece \\
\hline Berlin & 4 & Germany & Budapest & 4 & Hungary \\
\hline Hamburg & 2 & Germany & Dublin & 4 & Ireland \\
\hline Munich & 4 & Germany & Rome & 4 & Italy \\
\hline Cologne & 1 & Germany & Milan & 3 & Italy \\
\hline Frankfurt & 4 & Germany & Naples & 3 & Italy \\
\hline Essen & 2 & Germany & Turin & 3 & Italy \\
\hline Stuttgart & 4 & Germany & Palermo & 3 & Italy \\
\hline Leipzig & 1 & Germany & Genova & 1 & Italy \\
\hline Dresden & 4 & Germany & Florence & 3 & Italy \\
\hline Dortmund & 1 & Germany & Bari & 3 & Italy \\
\hline Düsseldorf & 1 & Germany & Bologna & 4 & Italy \\
\hline Bremen & 1 & Germany & Catania & 2 & Italy \\
\hline Hanover & 4 & Germany & Venice & 1 & Italy \\
\hline Nuremberg & 2 & Germany & The Hague & 2 & The Netherlands \\
\hline Bochum & 1 & Germany & Amsterdam & 4 & The Netherlands \\
\hline Freiburg im Breisgau & 2 & Germany & Rotterdam & 4 & The Netherlands \\
\hline Augsburg & 2 & Germany & Utrecht & 4 & The Netherlands \\
\hline Bonn & 4 & Germany & Eindhoven & 2 & The Netherlands \\
\hline Karlsruhe & 4 & Germany & Warsaw & 4 & Poland \\
\hline Saarbrücken & 1 & Germany & Lódz & 1 & Poland \\
\hline Duisburg & 4 & Germany & Kraków & 4 & Poland \\
\hline Mannheim & 4 & Germany & Wroclaw & 4 & Poland \\
\hline Münster & 2 & Germany & Poznan & 4 & Poland \\
\hline Aachen & 1 & Germany & Gdansk & 4 & Poland \\
\hline Tallinn & 1 & Estonia & Lublin & 2 & Poland \\
\hline Madrid & 3 & Spain & Katowice & 1 & Poland \\
\hline Barcelona & 3 & Spain & Lisbon & 4 & Portugal \\
\hline Valencia & 2 & Spain & Porto & 4 & Portugal \\
\hline Seville & 2 & Spain & Stockholm & 2 & Sweden \\
\hline Zaragoza & 4 & Spain & Gothenburg & 3 & Sweden \\
\hline Málaga & 2 & Spain & Malmö & 3 & Sweden \\
\hline Las Palmas & 3 & Spain & Ljubljana & 4 & Slovenia \\
\hline Bilbao & 4 & Spain & Bratislava & 2 & Slovak Republic \\
\hline Helsinki & 2 & Finland & London & 2 & United Kingdom \\
\hline Paris & 2 & France & Birmingham (UK) & 3 & United Kingdom \\
\hline Lyon & 2 & France & Leeds & 1 & United Kingdom \\
\hline Toulouse & 2 & France & Bradford & 2 & United Kingdom \\
\hline Strasbourg & 2 & France & Liverpool & 2 & United Kingdom \\
\hline Bordeaux & 2 & France & Manchester & 3 & United Kingdom \\
\hline Nantes & 2 & France & Cardiff & 3 & United Kingdom \\
\hline Lille & 2 & France & Sheffield & 2 & United Kingdom \\
\hline Montpellier & 2 & France & Bristol & 4 & United Kingdom \\
\hline Saint-Étienne & 2 & France & Newcastle & 4 & United Kingdom \\
\hline Rennes & 2 & France & Leicester & 1 & United Kingdom \\
\hline Grenoble & 2 & France & Portsmouth & 2 & United Kingdom \\
\hline Toulon & 2 & France & Nottingham & 1 & United Kingdom \\
\hline Marseille & 4 & France & Glasgow & 2 & United Kingdom \\
\hline Nice & 2 & France & Edinburgh & 1 & United Kingdom \\
\hline Rouen & 1 & France & & & \\
\hline
\end{tabular}


Appendix 1-3. Metropolitan area names in United States (US)

\begin{tabular}{|c|c|c|c|}
\hline Metropolitan area name & Cluster & Metropolitan area name & Cluster \\
\hline Seattle & 2 & Wichita & 3 \\
\hline Portland & 3 & Richmond & 3 \\
\hline Minneapolis & 4 & Norfolk-Portsmouth-Chesapeake-Virginia Beach & 4 \\
\hline Milwaukee & 3 & Fresno & 3 \\
\hline Madison & 1 & Las Vegas & 4 \\
\hline Buffalo & 4 & Nashville & 4 \\
\hline Grand Rapids & 3 & Tulsa & 1 \\
\hline Albany & 3 & Raleigh & 3 \\
\hline Detroit & 3 & Oklahoma City & 3 \\
\hline Boston & 3 & Charlotte & 3 \\
\hline Chicago & 4 & Albuquerque & 2 \\
\hline Providence & 3 & Memphis & 4 \\
\hline Toledo & 4 & Little Rock & 3 \\
\hline Cleveland & 3 & Los Angeles & 2 \\
\hline Des Moines & 3 & Columbia & 1 \\
\hline Omaha & 1 & Atlanta & 4 \\
\hline Akron & 2 & Phoenix & 4 \\
\hline New York & 3 & Birmingham & 1 \\
\hline Salt Lake City & 2 & Dallas & 3 \\
\hline Pittsburgh & 3 & San Diego & 3 \\
\hline Harrisburg & 1 & Fort Worth & 3 \\
\hline Philadelphia & 3 & Charleston & 1 \\
\hline Columbus & 3 & Tucson & 3 \\
\hline Denver & 4 & El Paso & 4 \\
\hline Indianapolis & 3 & Baton Rouge & 4 \\
\hline Dayton & 3 & Austin & 4 \\
\hline Baltimore & 2 & Jacksonville & 1 \\
\hline Cincinnati & 1 & New Orleans & 4 \\
\hline Washington & 4 & Houston & 4 \\
\hline Kansas City & 1 & San Antonio & 1 \\
\hline Colorado Springs & 1 & Orlando & 4 \\
\hline Saint Louis & 4 & Clearwater/Saint Petersburg & 4 \\
\hline Sacramento/Roseville & 3 & Tampa & 1 \\
\hline Louisville & 1 & Miami & 2 \\
\hline San Francisco & 3 & Mcallen & 1 \\
\hline
\end{tabular}


Appendix 2. Results of determinants analysis (Dependent variable is $\mathrm{CO}_{2} / \mathrm{POP}$ )

\begin{tabular}{|c|c|c|c|c|c|}
\hline VARIABLES & All sample & Cluster 1 & Cluster 2 & Cluster 3 & Cluster 4 \\
\hline AU\&CA $\times$ DENS & $-0.0472 * * *$ & $-0.545^{* * *}$ & $0.00353^{* * *}$ & N.A. & $1.011^{* * *}$ \\
\hline AU\&CA ×COMM & $-0.478^{* * *}$ & $-2.122 * * *$ & $0.0552 * * *$ & N.A. & $-11.72 * * *$ \\
\hline AU\&CA $\times$ CORE & -0.0238 & $3.484 * * *$ & $0.128 *$ & N.A. & $13.23^{* * *}$ \\
\hline CL\&MX×DENS & $0.000141^{* * *}$ & $0.00331^{* * *}$ & $0.000522 * * *$ & $0.000544 * * *$ & $-0.00816^{*}$ \\
\hline CL\&MX×COMM & $0.0125 * * *$ & $0.219 * * *$ & 0.00270 & $-0.0123 * * *$ & $0.706^{* * *}$ \\
\hline CL\&MX $\times$ CORE & $-0.00803^{*}$ & $0.371^{* * *}$ & -0.0660 & $-0.0718 * * *$ & $-0.386 * * *$ \\
\hline EU×DENS & -0.00151 & -0.00435 & $0.00207 * * *$ & $0.000393 * *$ & 0.00315 \\
\hline $\mathrm{EU} \times \mathrm{COMM}$ & $-0.122 * *$ & $-0.244^{* *}$ & 0.0302 & 0.00162 & -0.0980 \\
\hline $\mathrm{EU} \times \mathrm{CORE}$ & -0.0359 & -0.129 & 0.0177 & 0.0377 & 0.0782 \\
\hline $\mathrm{JP} \& \mathrm{KR} \times \mathrm{DENS}$ & 0.000600 & $-0.00383 * * *$ & $0.000128 * * *$ & N.A. & $-0.00164 * * *$ \\
\hline $\mathrm{JP} \& \mathrm{KR} \times \mathrm{COMM}$ & -0.0966 & $-0.174 * * *$ & $0.0129 * * *$ & N.A. & $-0.0363 * * *$ \\
\hline JP\&KR×CORE & $-0.158^{* *}$ & $-0.0989 * * *$ & 0.0106 & N.A. & $0.0995 * * *$ \\
\hline US $\times$ DENS & $-0.000517 * * *$ & $0.0270 * * *$ & $0.00567 * * *$ & $0.00511^{* * *}$ & $-0.0169 * * *$ \\
\hline US×COMM & $0.0290 * * *$ & $0.235^{* * *}$ & $0.0331^{* * *}$ & $-0.00855^{* * *}$ & $-0.0845^{* * *}$ \\
\hline US $\times$ CORE & $0.0289 * * *$ & $0.105^{* * *}$ & $0.198 * * *$ & $0.0152 * * *$ & $-0.0599 * * *$ \\
\hline 2005 year dummy & -0.0976 & 0.327 & $-0.202 * *$ & -0.383 & -0.224 \\
\hline 2008 year dummy & -0.636 & -0.455 & $-0.526 * * *$ & -0.919 & -1.020 \\
\hline Constant & $63.34 * *$ & $-34.92 * * *$ & -7.607 & 1.348 & -0.0841 \\
\hline Observations & 828 & 162 & 291 & 180 & 195 \\
\hline R-squared & 0.292 & 0.640 & 0.737 & 0.474 & 0.512 \\
\hline
\end{tabular}

Note $1: *$ denotes significance at $10 \%$ level, $* *$ denotes significance at $5 \%$ level, $* * *$ denotes significance at $1 \%$ level.

Note 2: " N.A." indicates that there is no sample selected, as in cluster 3 in the AU\&CA and JP\&KR region groups. 
Appendix 3. Results of determinants analysis (Dependent variable is GDP/POP)

\begin{tabular}{|c|c|c|c|c|c|}
\hline VARIABLES & All sample & Cluster 1 & Cluster 2 & Cluster 3 & Cluster 4 \\
\hline AU\&CA $\times$ DENS & $-32.60 * * *$ & $-1,419 * * *$ & $-18.46^{* * *}$ & N.A. & 972.1 \\
\hline AU\&CA $\times C O M M$ & 1.845 & $-19,296 * * *$ & 122.6 & N.A. & $-9,538$ \\
\hline AU\&CA $\times$ CORE & 257.9 & $-29,108 * * *$ & 324.5 & N.A. & 10,746 \\
\hline CL\&MX $\times$ DENS & $0.151^{* * *}$ & $-9.544 * * *$ & $1.078 * * *$ & $0.975^{* * *}$ & $-23.86 * * *$ \\
\hline CL\&MX×COMM & $40.70 * * *$ & $27.67 * * *$ & $66.62 * * *$ & $-38.20 * * *$ & $580.7 * *$ \\
\hline CL\&MX $\times$ CORE & $220.1 * * *$ & $-39.18 * * *$ & $608.5^{* * *}$ & $63.46 * * *$ & 40.83 \\
\hline EU×DENS & $5.451 * *$ & 6.478 & $10.09 * * *$ & -2.126 & 8.181 \\
\hline $\mathrm{EU} \times \mathrm{COMM}$ & $325.2 * * *$ & $219.2^{*}$ & $598.9 * * *$ & -57.29 & $468.6^{* *}$ \\
\hline $\mathrm{EU} \times \mathrm{CORE}$ & 121.9 & -25.73 & $446.8 * * *$ & -88.73 & -108.9 \\
\hline$J P \& K R \times D E N S$ & -0.938 & $-5.705 * *$ & -0.915 & N.A. & $3.137 * * *$ \\
\hline $\mathrm{JP} \& \mathrm{KR} \times \mathrm{COMM}$ & $-89.77 * *$ & -106.7 & $-92.26 * * *$ & N.A. & $25.99 * * *$ \\
\hline $\mathrm{JP} \& \mathrm{KR} \times \mathrm{CORE}$ & -40.60 & 26.66 & -144.4 & N.A. & $85.98 * * *$ \\
\hline US $\times$ DENS & $18.46^{* * *}$ & $65.21 * * *$ & $-28.75^{* * *}$ & $18.28 * * *$ & $-4.629 * * *$ \\
\hline $\mathrm{US} \times \mathrm{COMM}$ & $70.45^{* * *}$ & $292.1 * * *$ & $-63.60 * * *$ & $37.35 * * *$ & $-33.35 * * *$ \\
\hline US $\times$ CORE & $-100.8^{* * *}$ & $104.4 * * *$ & $340.9 * * *$ & $-277.7 * * *$ & $-189.8^{* * *}$ \\
\hline 2005 year dummy & $2,899 * * *$ & $2,727 * * *$ & $2,912 * * *$ & $2,365 * *$ & $3,276 * * *$ \\
\hline 2008 year dummy & $4,224 * * *$ & $3,844 * * *$ & $4,552^{* * *}$ & $3,096 * * *$ & $4,726 * * *$ \\
\hline Constant & 25,986 & $17,920 * * *$ & 7,448 & 53,151 & $8,911^{* * *}$ \\
\hline Observations & 828 & 162 & 291 & 180 & 195 \\
\hline R-squared & 0.746 & 0.797 & 0.844 & 0.852 & 0.744 \\
\hline
\end{tabular}

Note $1: *$ denotes significance at $10 \%$ level, $* *$ denotes significance at $5 \%$ level, $* * *$ denotes significance at $1 \%$ level.

Note 2: "N.A." indicates that there is no sample selected, as in cluster 3 in the AU\&CA and JP\&KR region groups. 
Appendix 4. Results summary of determinants analysis of driving factors

\begin{tabular}{|c|c|c|c|c|c|c|c|c|c|c|}
\hline & & \multicolumn{3}{|c|}{ DENS } & \multicolumn{3}{|c|}{ COMM } & \multicolumn{3}{|c|}{ CORE } \\
\hline & & $\mathrm{CO}_{2} / \mathrm{GDP}$ & GDP/POP & $\mathrm{CO}_{2} / \mathrm{POP}$ & $\mathrm{CO}_{2} / \mathrm{GDP}$ & GDP/POP & $\mathrm{CO}_{2} / \mathrm{POP}$ & $\mathrm{CO}_{2} / \mathrm{GDP}$ & GDP/POP & $\mathrm{CO}_{2} / \mathrm{POP}$ \\
\hline \multirow{5}{*}{$\begin{array}{c}\text { AU\& } \\
\text { CA }\end{array}$} & All & -*** & -*** & -**** & -*** & & -*** & & & \\
\hline & C1 & & -*** & $-* * *$ & $+* * *$ & -**** & -**** & $+* * *$ & -*** & $+* * *$ \\
\hline & $\mathrm{C} 2$ & $+* * *$ & -*** & $+* * *$ & & & $+* * *$ & & & $+*$ \\
\hline & C3 & N.A. & N.A. & N.A. & N.A. & N.A. & N.A. & N.A. & N.A. & N.A. \\
\hline & C4 & $+* * *$ & & $+* * *$ & $-* * *$ & & $-* * *$ & $+* * *$ & & $+* * *$ \\
\hline \multirow{5}{*}{$\begin{array}{c}\text { CL\& } \\
\text { MX }\end{array}$} & All & $+* * *$ & $+* * *$ & $+* * *$ & $+*$ & $+* * *$ & $+* * *$ & -*** & $+* * *$ & $-*$ \\
\hline & C1 & $+* * *$ & $-* * *$ & $+* * *$ & $+* * *$ & $+* * *$ & $+* * *$ & $+* * *$ & $-* * *$ & $+* * *$ \\
\hline & $\mathrm{C} 2$ & $+* * *$ & $+* * *$ & $+* * *$ & & $+* * *$ & & $-*$ & $+* * *$ & \\
\hline & C3 & $+* * *$ & $+* * *$ & $+* * *$ & -*** & -*** & - *** & - **** & $+* * *$ & - *** \\
\hline & $\mathrm{C} 4$ & & - **** & —* & & $+* *$ & $+* * *$ & & & —*** \\
\hline \multirow{5}{*}{$\mathrm{EU}$} & All & $-*$ & $+* *$ & & - *** & $+* * *$ & -** & $-*$ & & \\
\hline & C1 & -*** & & & $-* * *$ & $+*$ & - ** & & & \\
\hline & C2 & & $+* * *$ & $+* * *$ & - **** & $+* * *$ & & & $+* * *$ & \\
\hline & C3 & & & $+* * *$ & & & & & & \\
\hline & C4 & & & & & $+* *$ & & $+* * *$ & & \\
\hline \multirow{5}{*}{$\begin{array}{c}\text { JP\& } \\
\text { KR }\end{array}$} & All & $+* * *$ & & & & -** & & -** & & -** \\
\hline & C1 & & -** & - **** & -* & & —*** & & & - **** \\
\hline & C2 & & & $+* * *$ & $+* *$ & -*** & $+* * *$ & & & \\
\hline & C3 & N.A. & N.A. & N.A. & N.A. & N.A. & N.A. & N.A. & N.A. & N.A. \\
\hline & C4 & -*** & $+* * *$ & -*** & -**** & $+* * *$ & -**** & $+* * *$ & $+* * *$ & $+* * *$ \\
\hline \multirow{5}{*}{ US } & All & - **** & $+* * *$ & -*** & -**** & $+* * *$ & $+* * *$ & $+* * *$ & $-* * *$ & $+* * *$ \\
\hline & C1 & -*** & $+* * *$ & $+* * *$ & $+* * *$ & $+* * *$ & $+* * *$ & $+* * *$ & $+* * *$ & $+* * *$ \\
\hline & $\mathrm{C} 2$ & $+* * *$ & -*** & $+* * *$ & $+* * *$ & - **** & $+* * *$ & $+* * *$ & $+* * *$ & $+* * *$ \\
\hline & C3 & —*** & $+* * *$ & $+* * *$ & —*** & $+* * *$ & —*** & $+* * *$ & -*** & $+* * *$ \\
\hline & $\mathrm{C} 4$ & -*** & —*** & —*** & —*** & —*** & —*** & $+* * *$ & —*** & —*** \\
\hline
\end{tabular}

Note $1: *$ denotes significance at $10 \%$ level, ${ }^{* *}$ denotes significance at $5 \%$ level, $* * *$ denotes significance at $1 \%$ level.

Note 2: "+" indicates that the sign of the coefficient score is positive; “-” indicates that the sign of the coefficient score is negative.

Note 3: "N.A." indicates that there is no sample selected, as in cluster 3 in the AU\&CA and JP\&KR region groups. 